\title{
KEPEMIMPINAN PEREMPUAN DALAM
}

PERSPEKTIF MASYARAKAT DESA

\author{
Oleh \\ Pieter Frits Emanratu \\ (Dosen STIA Saumlaki)
}

\begin{abstract}
The village is a local entity that is owned by local wisdom that is designated as one of the order of life in community life. Becoming a new phenomenon compilation in the village in the culture of the Tanimbar community is led by a woman whose essence has not yet received a proper portion of the village customary community. Based on these considerations, this research was conducted to find out Community Perceptions about the Leadership of Women Heads in Lauran Village, Tanimbar Selatan District, West Southeast Maluku Regency.

The research method used is descriptive qualitative research with data collection techniques namely; (1) Observation, (2) In-depth interview (in-depth interview), and (3) Literature study and tracking related research results. The final result obtained is the Election of Women as the Head of Lauran Village is a setting of interest groups, the Leadership of the Village Head of Women is relatively weak in Lauran village with the culture and characteristics of the villagers who demand it. Weak leadership of the village head. Determine development targets in lauran village.
\end{abstract}

\section{Keywords: Women's Leadership, Community Perception}

\begin{abstract}
Abstrak
Desa merupakan sebuah entitas lokal mempunyai kearifan lokal tersendiri yang diyakini sebagai sebagai sebuah tatanan hidup dalam kehidupan masyarakat. Menjadi sebuah fenomena yang baru ketika saat Desa dalam kultur masyarakat Tanimbar di pimpin oleh seorang Perempuan yang pada hakekatnya belum mendapatkan porsi yang layak dalam tatanan adat masyarakat desa. Berdasarkan permasalahan tersebut, Penilitian ini dilakukan untuk mengetahui Persepsi Masyarakat tentang Kepemimpinan Kepala Desa Perempuan di Desa Lauran Kecamatan Tanimbar Selatan Kabupaten Maluku Tenggara Barat.

Adapun metode penelitian yang digunakan adalah penelitian deskriptif kualitatif dengan teknik pengumpulan data yaitu;(1) Observasi, (2) Wawancara mendalam (in-depth interview), dan (3) Studi pustaka serta penelusuran hasil-hasilpenelitian yang terkait. Hasil akhir yang diperoleh adalah Terpilihnya Perempuan sebagai Kepala Desa Lauran merupakan setingan dari kelompok kepentingan, Kepemimpinan Kepala Desa Perempuan relatif lemah pada desa Lauran dengan budaya dan karakteristik masyarakat desa yang cenderung keras. Lemahnya kepemimpinan Kepala Desa berdampak pada kurangnya ketercapaian target-target pembangunan di desa lauran.
\end{abstract}

Kata Kunci : Kepemimpinan Perempuan, Persepsi Masyarakat 


\section{PENDAHULUAN}

Keberhasilan suatu organisasi sangat ditentukan oleh peranan seorang pemimpin karena pemimpin merupakan penggerak utama di dalam mewujudkan kesuksesan organisasi.Dalam mencapai kesuksesan tersebt, seorang pemimpin memerlukan bantuan dan dukungan dari bawahan agar tercipta kerjasama yang baik di dalam menjawab tujuan, tuntutan serta tantangan yang dihadapi oleh oraganisasi.

Kepemimpinan (leadership) dapat dikatakan sebagai cara dari seorang pemimpin (leader) dalam mengarahkan, mendorong dan mengatur seluruh unsurunsur di dalam kelompok atau organisasinya untuk mencapai suatu tujuan organisasi yang diinginkan. Pemimpin harus mengenal dan mengetahui orang-orang yang ia pimpin dalam. Pemimpin juga bertanggungjawab akan semua hal yang menyangkut organisasi yang ia jalankan. Oleh karena itu, kemampuan dan keterampilan dalam memimpin merupakan factor penting dalam efektifitas organisasi (Alaslan, 2021: 2)

Kepemimpinan adalah hubungan antar manusia yang saling memengaruhi untuk mewujudkan kepatuhan/ketaatan para pengikut atau bawahan karena dipengaruhi oleh kewibawaan pemimpin. Untuk itu ada tiga hal yang harus dikembangkan oleh seorang pemimpin yakni seorang pemimpin harus mampu memimpin dirinya sendiri (managingself), memimpin orang (mananging people), dan memimpin tugas (mananging job). Efektivitas dalam melaksanakan kepemimpinan harus dimulai dari dirisendiri. Tidak mungkin seorang pemimpin yang gagal membuat dirinya efektif akan berhasil dalam mengefektifkan orang lain ataupun pekerjaannya (Kartono, 2013).

Menurut Supartiningsih (2003), data statistik seluruh dunia selalu menunjukan bahwa angka partisipasi perempuan dalam pasar kerja dan politik selalu lebih kecil dari laki-laki, sementara Astuti menerangkan bahwa faktor utama yang menghambat kesempatan perempuan untuk terjun dalam dunia politik yaitu pandangan stereotip bahwa dunia politik adalah dunia yang keras, memerlukan akal ,dunia yang penuh debat,dan membutuhkan pikiranpikiran cerdas, yang kesemuanya diasumsikan milik laki-laki bukan milik perempuan. Perempuan tidak pantas berpolitik karena perempuan adalah penghuni dapur, tidak bisa berpikir rasional dan kurang berani mengambil resiko, memiliki tingkat keraguan yang cukup tinggi, takut terhadap fenomena masyarakat, memiliki tingkat pendidikan yang terbatas dan kurang memiliki akses dimasyarakat untuk menyampaikan pendapat dalam proses pengambilan keputusan.

Manusia sebagai makluk social memiliki keinginan, komitmen dan 
tanggungjawab untuk menjadi seorang pemimpin baik itu laki-laki maupun perempuan dalam setiap aspek kehidupan masyarakat baik itu pada jenjang pendidikan maupun sosial dan politik. Saat ini perempuan telah mendapat porsi yang istimewah yang membawa inspirasi dan kesejukan dalam pekerjaan. Hal ini menunjukan bahwa kaum perempuan juga dapat ikut berpartisipasi dalam mengisi pembangunan daerah. Perempuan senantiasa ditempatkan sebagai kaum lemah yang dikodrati untuk harus tunduk dan taat pada laki-laki, sebab pekerjaan yang berat selalu dikerjakan oleh laki-laki daripada perempuan. Namun dengan kondisi demikian, hanya sedikit perempuan yang terlibat dalam dunia politik, sehingga sebagian besar perempuan berada dalam sektor domestic.

Alaslan, (2021：95) mengatakan bahwa Pemimpin atau sang Patron merupakan motor atau daya penggerak semua sumber-sumber dan alat-alat (resources) yang tersedia dalam suatu organisasi, sehingga perempuan juga memiliki hak dan kewajiban yang sama dalam dunia politik meskipun partisipasi perempuan untuk terlibat dalam dunia politik masih rendah, terebih pada kepemimpinan lokal kedaerahan yang masih mempertahankan nilai-nilai kearifan lokal berupa adat, budaya maupun karakteristik masyarakat setempat.
Daerah-daerah di Timur Indonesia dengan karakteristik masyarakat serta adat dan budaya yang cenderung keras merupakan tantangan tersendiri jika dipimpin oleh seorang perempuan, salah satunya adalah di Kabupaten Maluku Tenggara Barat dimana derajat seorang perempuan sangat diutamakan akan tetapi dalam pemerintahan desa perempuan tidak atau bahkan jarang dilibatkan dalam pengambilan keputusan terutama saat upacara adat istiadat dalam sebuah desa, namun ditemukan bahwa ada perempuan yang bisa menjadi pemimpin, salah satunya adalah sebagai Kepala Desa. Hal ini seperti yang ditemui di Desa Lauran Kecamatan Tanimbar Selatan Kabupaten Maluku Tenggara Barat, dimana kepala desa yang memimpin saat ini adalah seorang perempuan dari 10 Kepala Desa yang ada di Kecamatan Tanimbar Selatan dan menjadi pusat perhatian masyarakat dalam perkembangannya kedepan sehingga perlu diketahui persepsi masyarakat terhadap kepemimpinan perempuan di Desa Lauran Kecamatan Tanimbar Selatan Kabupaten Maluku Tenggara Barat.

\section{METODE PENELITIAN}

Penelitian ini menggunakan jenis penelitian deskriptif dimana penelitian dilakukan untuk mengumpulkan data dan fakta-fakta dilapangan dari tokoh masyarakat, tokoh Adat dan tokoh Agama, 
yang berhubungan erat dengan objek penelitian kemudian dideskripsikan dan dianalisis berdasarkan kaidah-kaidah ilmu pengetahuan yang relevan.

Model penelitian yang digunakan adalah penelitian kualitatif yang bermaksud untuk menganalisa dan memahami serta mendeskripsikan fenomena tentang apa yang dialami oleh subjek penelitian misalnya perilaku, persepsi, motivasi, tindakan dan lain-lain secara holistic dan dengan cara deskripsi dalam bentuk kata-kata dan bahasa, pada suatu konteks khusus yang alamiah dan dengan memanfaatkan berbagai metode ilmiah. (Moleong, 2005).

Adapun jenis penelitian yang digunakan dalam rancangan penelitian ini adalah "deskriptif kualitatif", dimana peneliti berusaha mendeskripsikan data yang diambil di lapangan lalu dihubungkan dengan hasil wawancara mendalam untuk memberikan penjelasan terhadap temuan penelitian dan selanjutnya dianalisis untuk mendapatkan kesimpulan sebagai jawaban atas pertanyaan-pertanyaan penelitian.

Teknik analisis yang digunakan dalam penelitian ini yakni analisis isi yang dilakukan pada saat peneliti mulai melakukan penelitian dan pengumpulan data di lapangan sampai dengan selesai. Menurut Millesdan Huberman dalam Alaslan, (2021: 7) bahwa dalam penelitian kualitatif terdapat tiga alur kegiatan yang terjadi secara bersamaan yaitu :reduksi data, penyajian data, dan penarikan kesimpulan.

Reduksi data meliputi proses pemilihan, pemusatan perhatian, penyederhanaan, pengabstrakan dan transformasi data mentah yang muncul dari catatan-catatan yang tertulis dilapangan maupun hasil wawancara yang ada. Reduksi data ini merupakan bentuk analisis yang menajamkan, menggolongkan, membuang data yang tidak perlu, dan mengorganisasikan data hingga kesimpulan finalnya dapat diverifikasi. Proses penyajian data dilakukan untuk menyusun informasi yang terkumpul dan memungkinkan adanya upaya penarikan kesimpulan.Hal ini penting untuk memahami apa yang sedang terjadi dan apa yang dilakukan sehingg analisis yang dilakukan berdasarkan atas pemahaman yang di dapat dari penyajian-penyajian tersebut, dan kemudian Penarikan kesimpulan dilakukan untuk mengetahui arti dari semua data yang dikumpulkan mulai dari awal sampai akhir penelitian.

\section{HASIL DAN PEMBAHASAN}

Sebagaiamana metode yang digunakan dalam penelitian adalah metode Kualitatif yang mensyaratkan keterlibatan langsung Peneliti pada lokasi penelitian melalui suatu proses wawancara maupun pengumpulan dokumen terkait, maka telah dilakukan wawancara mendalam dengan beberapa perwakilan masyarakat yang dipilih secara acak dengan pertimbangan 
kebutuhan oleh peneliti diantaranya Ketua Dewan Gereja Katholik, Ketua Badan Permusyawaratan Desa, Perwakilan Pemuda dan Orangtua di Desa Lauran, ditemukan fakta menarik bahwa ternyata keistimewahan Desa Lauran sebagai satu-satunya Desa di Kabupaten Maluku Tenggara Barat, yang telah beralih nama menjadi Kabupaten Kepulauan Tanimbar tidak seistimewah penyelenggaraan pemerintahannya. Anggapan ini merupakan akumulasi dari pengamatan panjang kepemimpinan Kepala Desa yang terkesan tidak membawa perubahan yang signifikan dalam pembangunan Desa Lauran. Jalan- jalan utama yang rusak dan luput dari perhatian pemerintah, maraknya penjualan tanah warga, masalah batas tanah dengan desa tetangga, serta pemberian bantuan melalui program pemberdayaan yang dinilai tidak tepat sasaran, ditambah lagi dengan tranparansi keuangan Desa yang masi terus diperdebatkan merupakan catatan-catatan merah dalam Rapor Sang Kepala Desa. Sebagaiamana pengertian persepsi yang dirumuskan dalam Kamus Besar Bahasa Indonesia (Purwodarminto (1990), bahwa persepsi adalah tanggapan langsung dari suatu serapan atau proses seseorang mengetahui beberapa hal melalui pengindraan".

Pandangan ini berkembang dari hasil pengamatan masyarakat yang hidup dan berinteraksi secara bersama pada Desa Lauran. Senada dengan pandangan dari Ketua Dewan Gereja, Pernyataan dari (VB) sebagai Perwakilan Orang Tua juga memberi kesan yang sama tentang Kepemimpinan Kepala Desa yang dirasa kurang menyentuh kebutuhan dan persoalan mendasar pada Desa Lauran. Hal ini sejalan dengan pengertian masyarakat yang adalah kumpulan individuindividu yang saling bergaul berinteraksi karena mempunyai nilai-nilai, norma-norma, cara-cara dan prosedur yang merupakan kebutuhan bersama berupa suatu sistem adat istiadat tertentu yang bersifat kontinue dan terikat oleh suatu identitas bersama (Musadun dalam Adrianto, 2006).

Pernyataan $(\boldsymbol{F S})$ ini secara langsung membenarkan keterangan Ketua Dewan Gereja Katholik Lauran tentang tidak ada yang menonjol dari pemerintahan desa.Isuisu inklusif dalam kepemimpinan perempuan berdasarkan "atribut natural" perempuan yang sensitif terjawab dari keterangan para informan yang ada. Keresahan masyarakat sepertinya tidak diresponi oleh Pemerintah Desa dalam hal ini Kepala Desa, sehingga kesan yang terbangun adalah Kepala Desa kurang pekah atau sensitif dengan keresehan yang berkembang di tenga-tenga masyarakat.Dalam hal intuitif, Kepala Desa dianggap lebih mendengarkan pihak-pihak yang memiliki kedekatan emosional dengan beliau. Dan bukannya mendengarkan keluhan dari akal rumput di masyarakat, bahkan ada 
tuduhan yang berani dari masrakat bahwa Kepala Desa Lauran hanya satu yaitu Ibu Kades, tetapi dalam penyelenggaraan pemerintahannya ada dua Kepala Desa yakni Bapak dan Ibu Kepala Desa, Bapak disini ditujukakn kepada suami dari Kepala Desa yang dinilai ikut mencampuri urusan-urusan pemerintahan di Desa Lauran,

Budaya di daerah Tanimbar atau Kabupaten Maluku Tenggara Barat memang terbilang keras, sehingga diperlukan kepimimpinan yang kuat dan tegas dari Kepala Desa untuk dapat mengatasi persoalan batas tanah serta hak kepemilikan secara adat dan lainnya. Pernayataan Ketua Dewan Gereja Katholik Desa Lauran menegaskan tentang arah kebijakan Pemimpin berlatar belakang Gender. Jika jumlah perempuan lebih banyak dalam proses pengambilan keputusan, maka fokus kehidupan politik juga akan berubah. Dampak yang paling jelas adalah akan terjadinya perluasan wilayah politik ke arah masalah-masalah dan isu-isu yang semula dianggap bukan isu politik seperti kesejahteraan anak, perlindungan terhadap reproduksi perempuan, dan lainlain. Kehidupan politik barangkali juga akan lebih bermoral karena perempuan lebih mementingkan isu politik konvensional seperti ekonomi, pendidikan, perumahan, lingkungan, kesejahteraan sosial daripada politik keras (hard politic) seperti peningkatan tentara, perang, pembelian senjata, dan membuat senjata nuklir (Astuti,
2011). Dengan demikian, berdasar pada keterangan informan yang kesemuanya mengarah pada ketidakpuasan terhadap kepemimpinan Kepala Desa dengan alasan yang sama namun penjelasan yang variatif, maka konstruksi kajian analisa masalah yang ada adalah bahwa Kepemimpinan Perempuan memang dapat mengalihkan fokus kebijakan politik pembangunan tetapi harus disesuaikan dengan keadaan sosial dan budaya setempat. Sensitifitas dari perempuan bilah dikelolah dan dikontrol dengan baik akan berdampak positif, yakni kepekahan terhadap fenomenah yang berkembang di masyarakat untuk selanjutnya dikonkretkan dalam kegiatankegiatan yang responsive dan soluktif. Sebaliknya, sensitifitas yang tidak terkontrol berdampak pada emosional yang berlebihan sebagai buah dari ego pribadi maupun kelompok kepetingan yang justru tidak baik dijadikan dasar pengambilan keputusan. Kekuatan dan ketegasan pemimpin memang tidak selalu dilihat dari gender, tetapi diukur berdasarkan konsistensi antara kebijakan yang diputuskan serta realisasi kebijakan dimaksut. Pemimpin harusla memiliki gagasan besar soal rencana pembangunan sehingga ada kemandirian berfikir dan bertindak yang pada akhirnya mewujudkan kewibawahan dari pemimpin itu sendiri.

\section{KESIMPULAN}

Berdasarkan kajian dan analisa terkait Keterpilihan Perempuan sebagai Kepala 
Desa, Kepemimpinan Kepala Desa, Serta evaluasi Kepemimpinan Kepala Desa sebagaiaman diuraikan maka setidaknya dapat disimpulkan bahwa :

1. Terpilihanya Perempuan sebagai Kepala Desa Lauran tidak murni keinginan dari masyarakat tetapi terkesan dipaksakan oleh keadaan bahkan rekayasa elite group

2. Kepemimpinan dari Kepala Desa tidak menyesuaikan diri untuk memenuhi prinsip "atribut natural perempuan yang sensitif, intuitif, empati, suka merawat, mampu bekerjasama, dan mengakomodasi dapat menjadikan proses-proses organisasi menjadi efektif (Growe, 1999)"

3. Kurangnya capaian keberhasilan dari Kepala Desa selama periode kempemimpinannya

\section{SARAN}

1. Sistem, prosedur serta mekanisme pemilihan kepala desa mestilah lebih independen diberikan kewenangan pelaksanaannya secara mandiri kepada desa setempat.

2. Kepemimpinan perempuan haruslah disesuaikan dengan adat, budaya serta karakterikistik masyarakat setempat.

3. Kepemimpinan janganlah didasarkan pada kodrati gender, tetapi sebaiknya disesuaikan dengan kemampuan yang dimiliki.

\section{DAFTAR PUSTAKA}

Abdul Syani, 2007. Sosiologi Skematika, Teori dan Terapan. PT.Bumi Aksara Jakarta 2007.

Pengertian

Masyarakat.http://digilib.unila.ac.id/ 920/3/Bab\%202.pdf

Arikunto, Suharsimi. 2010. Prosedur Penelitian Suatu Pendekatan Praktik. Jakarta: Rineka Cipta.

Alaslan, Amtai. 2021. Persepsi Masyarakat dan Kepemimpinan Perempuan. Jurnal OTONOMI Ilmu Administrasi Vol. 10. No. 20

2021. Kemampuan Pemerintah Desa Dan Pelaksanaan Tugas Administrasi Pemerintahan. Jurnal OTONOMI Ilmu Administrasi Vol. 9. No. 17

,2021. Gaya Kepemimpinan dan Pembangunan Desa. Journal AdBisPower STIA Saumlaki Vol. 1. No. 1

Astuti, Tri Marhaeni P. 2011. Konstruksi Gender dalam Realitas Sosial. Semarang: Unnes Press.

Cipta Ningsih Utaryo. 1992. Permasalahan Perempuan Di Negara Berkembang. Yogyakarta: Tiara Wacana Yogya.

Dzuhayatin, Sri Ruhaini. 2011. Kepemimpinan

Perempuan Perempuan. Di Indonesia (Tantangan dan Peluang). http//perempuanpolitik.com/kepemi mpinan-perempuan-di Indonesia tantangan-dan-peluang/.

Kartini, Kartono. 1990. Psikologi Perkembangan Anak. Bandung. CV.Mandiri.

Lin Nan. 2004. Social Capital. A Theory of Social Structure and Action. United Kingdom (UK): Cambridge.

Luthfi,Asma dan Atika Wijaya.2011.Persepsi Masyarakat Sekarang Tentang Konservasi Lingkungan. Jurnal Komunitas, Vol. 3No. 1: 29-39.

Miftah,Toha.2003.Perilaku Organisasi, Konsep Dasar dan Aplikasinya. Jakarta: PT. Raja 
Grafindo Persada

Pieter, H. Z. \& Lubis, N. L. 2010 Pengantar Psikologi Dalam Keperawatan. Jakarta: Kencana

Purwodarminto, 1990. Teori Dan Pengertian Perubahan Sosial. http://google weblight.com/?liteurl=http://belajar psikologi.com/pengertianperubahan sosial/\&Ic=idID\&s=1\&m=936\&hos $\mathrm{t}=\mathrm{www}$.google.co.id\&ts $=15056176$ 24\&sig=ANTYL2tPvgCWI8vjy4_o AXuoD4IAsHBRw

Sugiyono. 2010. Metode Penelitian Pendidikan Pendekatan Kuantitatif, Kualitatif dan $R \& D$. Alfabeta: Bandung.

Supartiningsih .2003. Peran Ganda Perempuan, Sebuah Analisis Filosofis Kritis. Jurnal Filsafat, Jilid 33.Nomor1: 42-54.

Situmorang, Nina Zulida. 2011. Gaya Kepemimpinan Perempuan. Jurnal Proceeding PESAT. Vol 4.I SSN 18582559. 